\title{
AMINO-(GD)NITRATE COMBUSTION PROCESS: THE INFLUENCE OF AN AMINO ACID ON THE FINAL PRODUCT
}

\author{
1,2'Lubomíra KUZNÍKOVÁ, 'PPavlína PEIKERTOVÁ, 'Marianna HUNDÁKOVÁ, ${ }^{1,3}$ Pavel MANČíK,

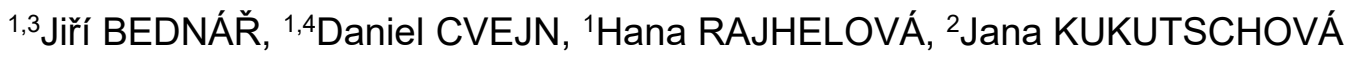 \\ ${ }^{1}$ Nanotechnology Centre, VSB - Technical University of Ostrava, Ostrava, Czech Republic, EU, \\ lubomira.kuznikova@vsb.cz, pavlina.peikertova@vsb.cz, marianna.hundakova@vsb.cz, \\ daniel.cvejn@vsb.cz, hana.rajhelova@vsb.cz, pavel.mancik@vsb.cz, jiri.bednar@vsb.cz \\ ${ }^{2}$ Center of Advanced Innovation Technologies, VSB - Technical University of Ostrava, \\ Czech Republic,EU, lubomira.kuznikova@vsb.cz, jana.kukutschova@vsb.cz \\ 3/T4Innovations National Supercomputing Center, VSB - Technical University of Ostrava, \\ Czech Republic, EU, pavel.mancik@vsb.cz, jiri.bednar@vsb.cz \\ ${ }^{4}$ ENET Centre, VSB - Technical University of Ostrava, Ostrava, Czech Republic, EU, \\ daniel.cvejn@vsb.cz
}

https://doi.org/10.37904/nanocon.2019.8590

\begin{abstract}
Combustion methods are a promising strategy for the lanthanide oxide nanomaterials preparation. They are environmentally friendly, they have feasible experimental setup and can be easily upscaled. As a part of our broader research dealing with amino acid-nitrate processes, several samples of the $\mathrm{Gd}_{2} \mathrm{O}_{3}$, synthesized with four amino acids (alanine, glycine, proline, and serine) were prepared to observe an influence of amino acids on the final product's nature and morphology. All of the four samples were prepared via thermal decomposition of a transient complex formed in situ from $\mathrm{Gd}\left(\mathrm{NO}_{3}\right)_{3} \cdot 6 \mathrm{H}_{2} \mathrm{O}$ and selected amino acid. The resulting products were characterized by the $\mathrm{X}$-ray powder diffraction analysis, which demonstrated an influence of amino acids on the crystal structure of the final $\mathrm{Gd}_{2} \mathrm{O}_{3}$ nanocrystallites. The elemental composition and morphology of the samples of $\mathrm{Gd}_{2} \mathrm{O}_{3}$ were examined by the scanning electron microscopy with energy dispersive X-ray spectroscopy. We also measured particle size and particle size distribution as all final products $\left(\mathrm{Gd}_{2} \mathrm{O}_{3}\right)$ had tendency to form agglomerates. Fourier-transform infrared spectroscopy and $\mathrm{X}$-ray powder diffraction analysis revealed that glycine and proline, used as an organic fuel, yields the cubic structure of $\mathrm{Gd}_{2} \mathrm{O}_{3}$ nanocrystallites.
\end{abstract}

Keywords: $\mathrm{Gd}_{2} \mathrm{O}_{3}$, thermal decomposition, amino acid-nitrate process, nanocrystallites

\section{INTRODUCTION}

Lanthanide oxides have gained a lot of attention due to their diverse use for applications such as in the photonics, catalysis, nuclear industry, and electronics [1]. Among the important lanthanides oxides, $\mathrm{Gd}_{2} \mathrm{O}_{3}$ gains a significant importance due to its good crystallographic stability up to $2325{ }^{\circ} \mathrm{C}$, high mechanical strength, and excellent thermal conductivity together with relatively high dielectric constant, wide band gap [2], and versatile and tunable magnetic properties [3]. Nanomaterials based on $\mathrm{Gd}_{2} \mathrm{O}_{3}$ have been used for example in the solid-state lasers [4], in the solid oxide fuel cells as an electrolyte [5], in the temperature sensors [6] or as the contrast agents in the magnetic resonance imaging [7].

The promising perspective method for preparation of $\mathrm{Gd}_{2} \mathrm{O}_{3}$ could be amino acid-nitrate combustion process $[8,9]$ which appear to be effective, low-cost, environmentally friendly, experimentally undemanding and perfectly scalable [10]. Amino acid-nitrate process use amino acid as a fuel and nitrate (or nitrate hydrate) as an oxidant in the presence of source of the inner transition metal [11,12]. Different amino acids have already been used in the combustion processes for preparation of nanomaterials based on lanthanides, such as for 
example alanine $[4,6,13,14]$, glycine $[5,13,14]$ or serine $[13,14]$. It has been found that the type of source of the inner transition metal and amino acids has an influence on the shape and grain size of the nanocomposite $[13,14]$. It was further observed that different types of organic fuels (urea and alanine or their mixture) have an influence on the temperature of combustion, crystallographic structure, morphology and resulting particle sizes [6]. It has also been found that the particle size increased with increasing calcination temperature in the combustion synthesis (from $25 \mathrm{~nm}$ at $800^{\circ} \mathrm{C}$ to $200 \mathrm{~nm}$ at $1100^{\circ} \mathrm{C}$ ) [4].

Consequently we chose to prepare four various samples of $\mathrm{Gd}_{2} \mathrm{O}_{3}$ nanocrystallites using amino acid(Gd)nitrate combustion process for observation an influence of an amino acids on the nature and morphology of the final product. Four different amino acids were selected for preparation. Specifically, glycine and alanine as a representative of amino acids with a side aliphatic chain, serine as a representative of amino acids with a hydroxyl group on the side chain, and proline as a representative of an imino acids.

\section{EXPERIMENTAL}

\subsection{Synthesis of the samples}

We used the water demineralized by the column Demiwa 10 (Watek) as a solvent. Gadolinium nitrate $\left(\mathrm{Gd}\left(\mathrm{NO}_{3}\right)_{3} \cdot 6 \mathrm{H}_{2} \mathrm{O}\right)$ was purchased from Acros Organics (Belgium) in $99.9 \%$ quality. Alanine $\left(\mathrm{C}_{3} \mathrm{H}_{7} \mathrm{NO}_{2}\right)$ was purchased from VWR Chemicals (Czech Republic) in high purity ( $\geq 99 \%)$ and glycine $\left(\mathrm{NH}_{2} \mathrm{CH}_{2} \mathrm{COOH}\right)$ was purchased from Penta (Czech Republic) in p.a. quality. Proline $\left(\mathrm{C}_{5} \mathrm{H}_{9} \mathrm{NO}_{2}\right)$ and serine $\left(\mathrm{C}_{3} \mathrm{H}_{7} \mathrm{NO}_{3}\right)$ was purchased from Alfa Aesar (USA) in $99.9 \%$ quality.

Samples of $\mathrm{Gd}_{2} \mathrm{O}_{3}$ were prepared according to the protocol used as in our previous study [15] by mixing equivalent portions of $0.5 \mathrm{~mol} \cdot \mathrm{dm}^{-3}$ solutions of $\mathrm{Gd}\left(\mathrm{NO}_{3}\right)_{3} \cdot 6 \mathrm{H}_{2} \mathrm{O}$ and particular amino acid (alanine - Ala, glycine - Gly, proline - Pro, serine - Ser) and dried at $120^{\circ} \mathrm{C}$ until viscous gel was formed. The gel was then calcined (High Temperature Equipment LAC/LMH) in the temperature $600^{\circ} \mathrm{C}$ for 1 hour. Prepared samples, marked Gd_Ala, Gd_Gly, Gd_Pro, and Gd_Ser, were subsequently analysed by X-ray powder diffraction analysis (XRPD), Fourier-transform infrared spectroscopy (FTIR), scanning electron microscopy with energy dispersive X-ray spectroscopy (SEM/EDS), and particle size and particle size distribution technique (PS/PSD).

\subsection{Characterization of the samples}

XRPD was performed using the X-ray diffractometer Ultima IV (Rigaku, Japan), operated at $40 \mathrm{kV}$ and $40 \mathrm{~mA}$ with CuKa radiation of wavelength $\lambda=0.154060 \mathrm{~nm}$ (reflection mode, Bragg-Brentano arrangement with scintillation detector). The XRPD patterns were recorded in the $10-70^{\circ}(2 \theta)$ range with a scanning rate of $2.4 \%$ min. The samples were placed in a ground glass depression in the sample holder and flattened with a glass slide. Phase analysis was evaluated by database PDF-2 Release 2011. Graphics processing XRPD patterns was made using OriginPro8. The crystallite size of the most intense reflection of Gd_Ala,Gd_Gly, Gd_Pro, and Gd_Ser were determined using the Scherrer formula [16].

Single reflection ATR technique with diamond crystal was used for measurements of mid-FTIR spectra (Nicolet iS10, Thermo Scientific, USA). Spectra were recorded in the range of $400-4000 \mathrm{~cm}^{-1}$, however, only region of interest $\left(400-1800 \mathrm{~cm}^{-1}\right)$ is shown in FTIR spectra. All obtained data were processed using the OMNIC software.

For the SEM/EDS analysis, samples were attached to the carbon conductive tape and sputtered with two layers of gold (POLARON SC 7640 sputter coater). Scanning electron microscope Quanta 450 FEG (FEI) was used for revealing of the morphology and EDS analysis was performed with analyser APOLLO X (EDAX) for qualitative analysis of the presented elements. Images were taken by using SE detector (secondary electron detector) at $15 \mathrm{kV}$. The resulting images were edited by ImageJ program. 
Particle size (PS) and particle size distribution (PSD) analyses were performed by dynamic light scattering (DLS) method on the analyzer Malvern Zen 3600 Zetasizer. The same instrument was used to measure their zeta potential. To perform these analyses, the powder samples $(0.01 \mathrm{~g})$ were diluted in $50 \mathrm{ml}$ of demineralized water and disintegrated in in self-constructed ultrasonic reactor with the acoustic power of $0.5 \mathrm{~kW} / \mathrm{l}$ for 3 minutes [17]. The samples were then immediately injected into a cell for zeta potential and particle size distribution measurement. The refractive indexes of lanthanide oxides (1.950) and distilled water (1.333) were determined in our previous research [15].

\section{RESULT AND DISCUSSION}

The X-ray diffraction patterns of prepared gadolinium oxides are shown in Figure 1. Samples contained either monoclinic or cubic crystal structures of $\mathrm{Gd}_{2} \mathrm{O}_{3}$. Monoclinic crystal structures were identified in the sample Gd_Ala (PDF card No. 00-043-1015) and Gd_Ser (PDF card No. 00-012-0474), while cubic crystal structures were identified in the sample Gd_Gly and Gd_Pro (PDF card No. 01-074-8036). No additional reflections of other phases were observed in the XRPD patterns, which indicates the crystallographic purity of prepared oxides. The crystallite size of the most intense reflections $(2,2,2)$ and $(1,1,1)$ were determined to $10.1 \mathrm{~nm}$ for Gd_Gly, $10.6 \mathrm{~nm}$ for Gd_Pro, $16.8 \mathrm{~nm}$ for Gd_Ala, and $40.8 \mathrm{~nm}$ for Gd_Ser. From these results it is evident, that the type of the amino acid has an affect the crystal structure and the crystallite size of the resulting product. Moreover, the same type of amino acid (Ala and Gly - amino acids with a side aliphatic chain) does not produce $\mathrm{Gd}_{2} \mathrm{O}_{3}$ of the same crystalline structure as would be expected, but produces $\mathrm{Gd}_{2} \mathrm{O}_{3}$ of different crystal structures.

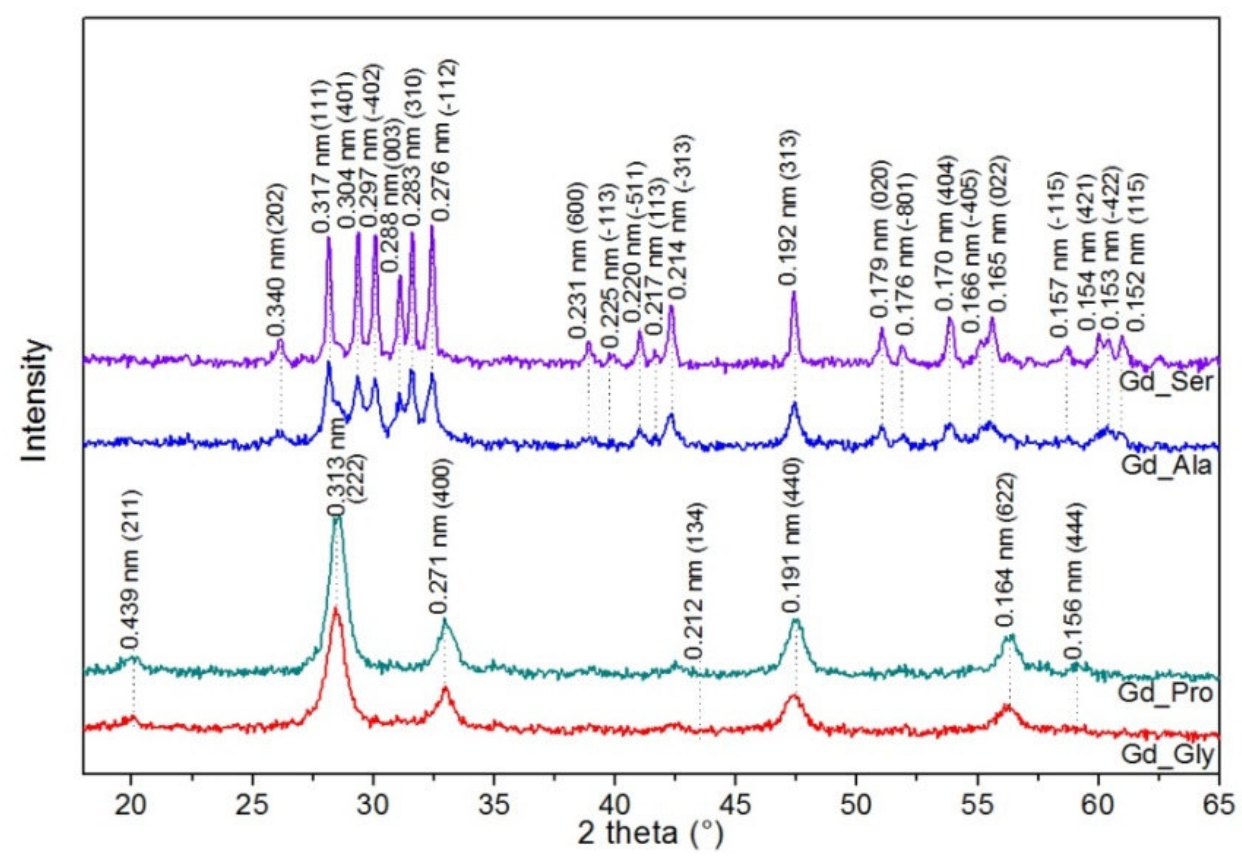

Figure $1 \mathrm{X}$-ray diffraction patterns of the samples $\mathrm{Gd}_{2} \mathrm{O}_{3}$ prepared using different amino acids - alanine (Gd_Ala), glycine (Gd_Gly), proline (Gd_Pro), and serine (Gd_Ser)

FTIR spectra are presented in the Figure 2. All spectra show bands typical for the $\mathrm{Gd}_{2} \mathrm{O}_{3}$ [18]. By comparing the spectra, it is clear, that Gd_Ala and Gd_Ser have similar features and as well Gd_Gly with Gd_Pro. These results are in the agreement with the previous XRPD results. It could be also mentioned that main band corresponding Gd-O (538 cm-1, arrow in the Figure 2) bond is more intensive and narrow for Gd_Gly and Gd_Pro samples, which is probably caused by the cubic crystal structure. 


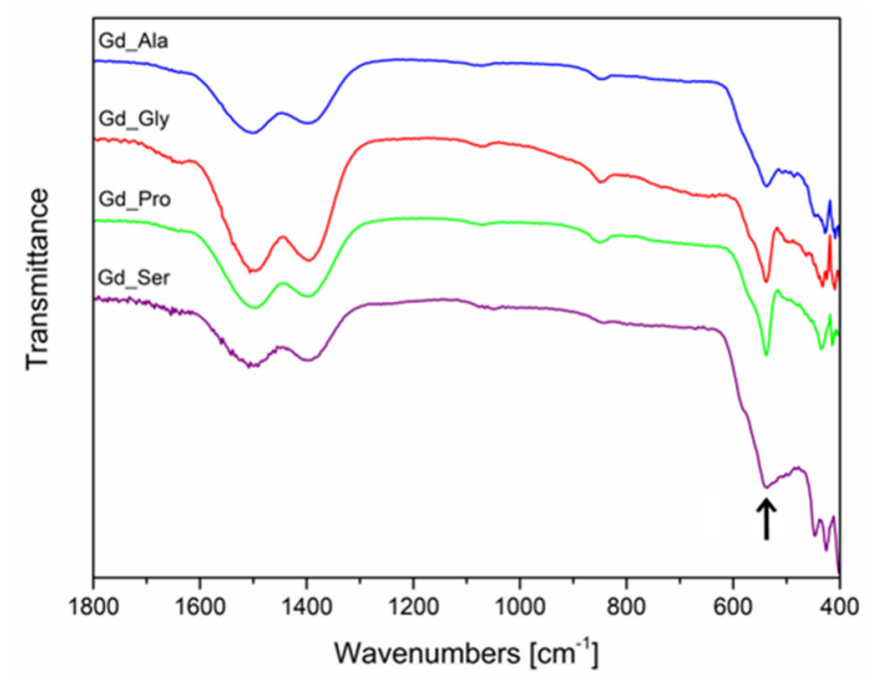

Figure 2 FTIR spectra of the samples Gd_Ala, Gd_Gly, Gd_Pro, and Gd_Ser

From the SEM images (Figure 3) we can see that $\mathrm{Gd}_{2} \mathrm{O}_{3}$ forms an aggregated meso- and macro-porous network structure like foam. We can see in the taken SEM images that the type of the amino acid did not affected resulting morphology, so it has to be influenced by the reaction mechanisms. However, detailed description and explanation of this phenomenon is under investigation. EDS then confirmed the expected presence of only gadolinium and oxygen in the prepared samples. These results are in correlation with the results obtained by XRPD and FTIR.
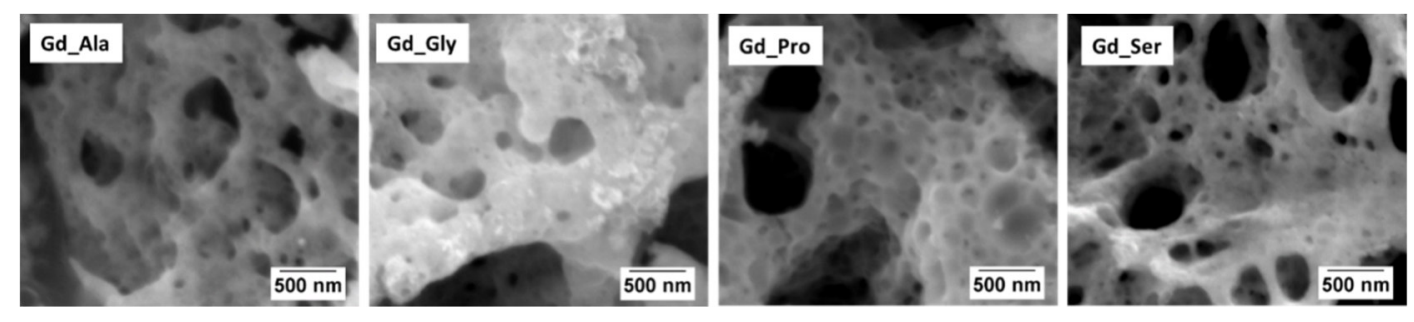

Figure 3 SEM images of the all experimental $\mathrm{Gd}_{2} \mathrm{O}_{3}$ samples

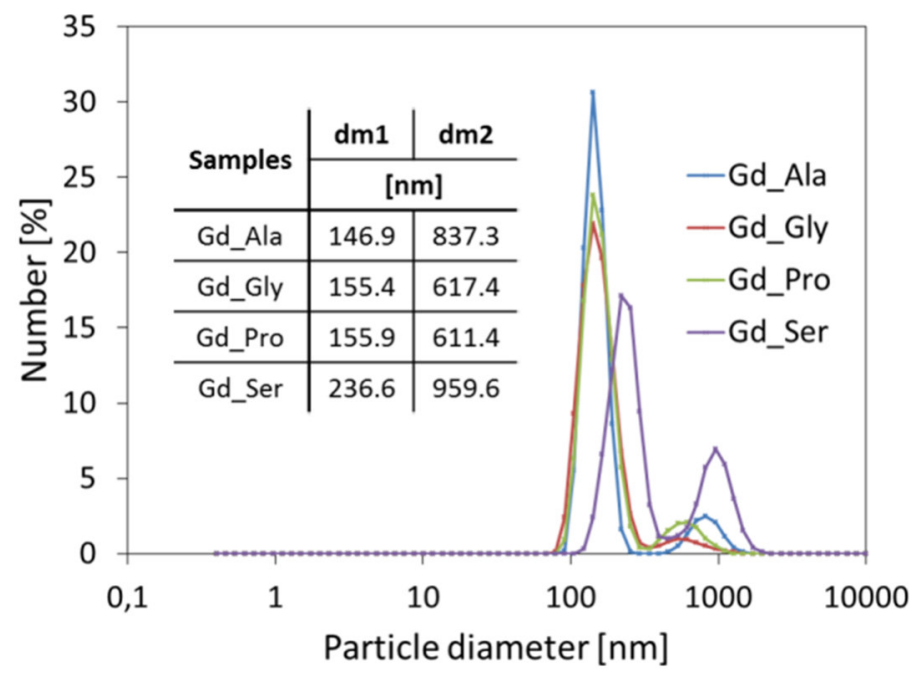

Figure 4 Particle size distributions of samples in lognormal scale and their corresponding mean sizes for two highest peaks of their bimodal distribution $\mathrm{dm} 1$ and $\mathrm{dm} 2$ 
The particle size measurement in the Figure 4 shown bimodal distribution with corresponding mean sizes dm1 and $\mathrm{dm} 2$ summarized in the inserted table. The bimodal character may have origin in the intensive reaggregation of smaller particles and in the incomplete disintegration of all aggregates to the same size. The zeta potential values (Table 1) show low values for all samples, which indicates unstable dispersion and the particle re-aggregation is highly expected. The extraordinary low zeta potential for the Gd_Ser sample then caused more rapid aggregation during measurement which can be seen as the shift in particle size distribution in comparison to the other samples.

Table 1 Zeta potential of $\mathrm{Gd}_{2} \mathrm{O}_{3}$ particles in the prepared dispersions. Higher absolute value implies higher stability

\begin{tabular}{|c|c|c|}
\hline Samples & $\begin{array}{c}\text { Zeta potential } \\
(\mathbf{m V})\end{array}$ & $\begin{array}{c}\text { St. Dev. } \\
(\mathbf{m V})\end{array}$ \\
\hline Gd_Ala & 20.90 & 1.42 \\
\hline Gd_Gly & 15.80 & 1.48 \\
\hline Gd_Pro & 18.10 & 0.93 \\
\hline Gd_Ser & 5.49 & 0.53 \\
\hline
\end{tabular}

\section{CONCLUSION}

We prepared four samples of nanocrystalline $\mathrm{Gd}_{2} \mathrm{O}_{3}$ (Gd_Ala, Gd_Gly, Gd_Pro, and Gd_Ser) using combustion process to observe an influence of selected amino acids on the final product's nature and morphology. Obtained samples were characterized by XRPD, FTIR, SEM/EDS, and PS/PSD techniques. We proved that amino acid-nitrate combustion process allows synthetize pure and homogeneous $\mathrm{Gd}_{2} \mathrm{O}_{3}$ structures. Electron microscopy revealed net-like structure created by aggregation of nanoparticles. The glycine and proline produced cubic $\mathrm{Gd}_{2} \mathrm{O}_{3}$ with comparable particles size, but alanine and serine produced monoclinic $\mathrm{Gd}_{2} \mathrm{O}_{3}$ with much different particles size. In addition, the same type of amino acid does not produce $\mathrm{Gd}_{2} \mathrm{O}_{3}$ of the same crystalline structure as would be expected. Finally, we discovered that type of the amino acid does not affect the morphology of the resulting product.

\section{ACKNOWLEDGEMENTS}

This work was supported by the Ministry of Education, Youth and Sports of the Czech Republic [grant numbers: SP2019/56 and SP2019/39], the program 'Support for Science and Research in the Moravian-Silesian Region 2017' (RRC/10/2017) from Moravian-Silesian Region [grant number 04766/2017/RRC], the ERDF (European Regional Development Fund) / ESF (European Social Fund) [grant numbers: CZ.02.1.01/0.0/0.0/17_048/0007399 and CZ.02.2.69/0.0/0.0/16_018/0002708], and the Technology Agency of the Czech Republic [grant number: EF16_013/0001791].

\section{REFERENCES}

[1] TSUZUKI, T., PIRAULT, E. and MCCORMICK, P. Mechanochemical synthesis of gadolinium oxide nanoparticles. Nanostructured Materials. 1999. vol. 11, no. 1, pp. 125-131.

[2] TAMRAKAR, R., BISEN, D. and BRAHME, N. Comparison of photoluminescence properties of $\mathrm{Gd}_{2} \mathrm{O}_{3} \mathrm{phosphor}$ synthesized by combustion and solid state reaction method. Journal of Radiation Research and Applied Sciences. 2014. vol. 7, no. 4, pp. 550-559.

[3] AHRÉN, M., SELEGÅRD, L., SÖDERLIND, F., LINARES, M., KAUCZOR, J., NORMAN, P., KÄLL, P.-O., and UVDAL, K. A simple polyol-free synthesis route to $\mathrm{Gd}_{2} \mathrm{O}_{3}$ nanoparticles for MRI applications: an experimental and theoretical study. Journal of Nanoparticle Research. 2012. vol. 14, no. 8. 
[4] LAISHRAM, K., MANN, R. and MALHAN, N. Microwave gel combustion synthesis and sinterability of Nd: GGG nanopowders. Journal of Rare Earths. 2014. vol. 32, no. 6, pp. 521-525.

[5] KULKARNI, S., DUTTAGUPTA, S. and PHATAK, G. Study of glycine nitrate precursor method for the synthesis of gadolinium doped ceria $\left(\mathrm{Ce}_{0.8} \mathrm{Gd}_{0.2} \mathrm{O}_{1.90}\right)$ as an electrolyte for intermediate temperature solid oxide fuel cells. $R S C$ Adv. 2014. vol. 4, no. 87, pp. 46602-46612.

[6] KRIŽAN, J., MAZAJ, M., KAUČIČ, V., BAJSIć, V., and MOŽINA, J. Synthesis of Er- and Yb-doped Gadolinium Oxide Polymorphs and Influence of Their Structures on Upconversion Properties. Acta Chimica Slovenica. 2014. vol. 61, no. 3, pp. 608-614.

[7] DARRAH, T., PRUTSMAN-PFEIFFER, J., POREDA, R., ELLEN CAMPBELL, M., HAUSCHKA, P., and HANNIGAN, R. Incorporation of excess gadolinium into human bone from medical contrast agents. Metallomics. 2009. vol. 1, no. 6, pp. 479-488.

[8] PUROHIT, R., SHARMA, B., PILLAI, K., and TYAGI, A. Ultrafine ceria powders via glycine-nitrate combustion. Materials Research Bulletin. 2001. vol. 36, no. 15, pp. 2711-2721.

[9] DALDOSSO, M., SOKOLNICKI, J., KEPINSKI, L., LEGENDZIEWICZ, J., SPEGHINI, A., and BETTINELLI, M. Preparation and optical properties of nanocrystalline $\mathrm{Lu}_{2} \mathrm{O}_{3}: \mathrm{Eu}^{3}$ phosphors. Journal of Luminescence. 2007. vol. 122-123, pp. 858-861.

[10] JIANG, L., LIU, W., WU, A., XU, J., LIU, Q., QIAN, G., and ZHANG, H. Low-temperature combustion synthesis of nanocrystalline $\mathrm{HoFeO}_{3}$ powders via a sol-gel method using glycin. Ceramics International. 2012. vol. 38, no. 5, pp. 3667-3672.

[11] MURRAY, E., TSAI, T. and BARNETT, S. A direct-methane fuel cell with a ceria-based anode. Nature. 1999. vol. 400, no. 6745, pp. 649-651.

[12] YILDıZ, Ö., SOYDAN, A.M., ATA, A., TUNABOYLU, B., AKıN, D., and IPCIZADE, E.F. Properties of Ceria Based Novel Anode Nanopowders Synthesized by Glycine-Nitrate Process. Acta Physica Polonica A. 2013. vol. 123, no. 2, pp. 432-435.

[13] SALEHI, Z., ZINATLOO-AJABSHIR, S. and SALAVATI-NIASARI, M. Novel synthesis of $\mathrm{Dy}_{2} \mathrm{Ce}_{2} \mathrm{O}_{7}$ nanostructures via a facile combustion route. RSC Advances. 2016. vol. 6, no 32, pp. 26895-26901.

[14] MORASSAEI, M., ZINATLOO-AJABSHIR, S. and SALAVATI-NIASARI, M. Simple salt-assisted combustion synthesis of $\mathrm{Nd}_{2} \mathrm{Sn}_{2} \mathrm{O}_{7}-\mathrm{SnO}_{2}$ nanocomposites with different amino acids as fuel: an efficient photocatalyst for the degradation of methyl orange dye. Journal of Materials Science: Materials in Electronics. 2016. vol. 27, no. 11, pp. 11698-11706.

[15] DĚDKOVÁ, K., KUZNÍKOVÁ, L'., PAVELEK, L., MATĚJOVÁ, K., KUPKOVÁ, J., ČECH BARABASZOVÁ, K., VÁŇA, R., BURDA, J., VLČEK, J., CVEJN, D., and KUKUTSCHOVÁ, J. Daylight induced antibacterial activity of gadolinium oxide, samarium oxide and erbium oxide nanoparticles and their aquatic toxicity. Materials Chemistry and Physics. 2017. vol. 197, pp. 226-235.

[16] SCHERRER, P. Estimation of the size and internal structure of colloidal particles by means of röntgen. Nachrichten von der Gesellschaft der Wissenschaften zu Göttingen. 1918. vol. 2, p. 96.

[17] BEDNÁŘ, J., MANČíK, P., SVOBODA, L., and DVORSKY, R. Enhanced Disintegration of Silicon Particles due to their Mutual Impact Caused by Ultrasonic Cavitation Bubbles. Key Engineering Materials. 2019, vol. 810, pp. 131136.

[18] SÖDERLIND, F., PEDERSEN, H., PETORAL, R., KÄLL, P.-O., and UVDAL, K. Synthesis and characterisation of $\mathrm{Gd}_{2} \mathrm{O}_{3}$ nanocrystals functionalised by organic acids. Journal of Colloid and Interface Science. 2005. vol. 288, no. 1 , pp. $140-148$. 